\title{
POSISI STRATEGIS DAN ARAH PENGEMBANGAN UNIT PELAKSANA TEKNIS DINAS (UPTD) MENJADI BADAN LAYANAN UMUM DAERAH (BLUD) DI PEMERINTAH PROVINSI JAWA TIMUR
}

\author{
Slamet Hari Sutanto \\ Badan Penelitian dan Pengembangan Provinsi Jawa Timur, slametharisutanto@gmail.com
}

\begin{abstract}
Abstrak
Keterbatasan sistem penganggaran pemerintah saat ini maka tidak semua urusan pemerintahan dan pembangunan untuk mewujudkan kesejahteraan rakyat tidak mungkin semuanya dibiayai oleh APBD. Pemprov Jatim saat ini sedang mendorong Unit Pelaksana Teknis Daerah (UPTD) yang ada di lingkungan SKPD mulai menggunakan sistem pengelolaan keuangan Badan Layanan Umum Daerah (BLUD). Kebijakan tersebut tercantum secara jelas dalam roadmap inovasi kebijakan fiskal Pemprov Jatim 20142019. Tujuan dari penelitian ini adalah untuk (1). Mengidentifikasi kondisi UPT-UPT di lingkungan Pemprov Jatim saat ini (2). Mengidentifikasi masalah dan tantangan yang dihadapi dalam pengembangan UPTD tersebut menjadi BLUD dan (3). Merumuskan strategi pengembangan yang dapat dilakukan Pemprov Jatim dalam pengembangan UPTD tersebut menjadi BLUD. Metode penelitian yang digunakan adalah metode campuran yaitu memadukan analisa data kualitatif dengan data kuantitatif dengan menggunakan matriks SWOT, kemudian untuk menentukan posisi strategis dan arah pengembangan dilakukan melalui analisis General Electrics (GE) matriks. Populasi dalam penelitian ini adalah seluruh Unit Pelaksana Teknis (UPT) di lingkungan Pemprov Jatim, sedangkan penarikan sampel dilakukan berdasarkan purposive sampling. Hasil penelitian menunjukan (1). UPT seperti UPT P2SKP Mayangan, UPT P2SKP Pondokdadap, UPT P2SKP Muncar, dan UPT PSMB-LT siap jika ditingkatkan statusnya menjadi BLUD melihat faktor kemampuan keuangan, kelengkapan sarana dan prasarana serta potensi yang dimilikinya (2). Beberapa UPT seperti UPT PB Palawija, UPT PB Holtikultura, dan UPTIK Kayu bisa ditingkatkan menjadi BLUD, tetapi perlu dipersiapkan terlebih dahulu terutama sarana prasarana pendukung terutama teknologi aspek teknologi beserta SDM pendukungnya, dan juga permodalan serta promosi untuk mengembangkan ke pasar yang lebih luas. (3). Sedangkan UPT Pelatihan Kerja (BLKI) Singosari dan Jember, disebabkan karakter pelayananya yang spesifik dan segmen pelayanan yang khusus sehingga ketergantungan kepada APBD/APBN masih sangat tinggi, masih sulit dari segi kemadirian untuk ditingkatkan statusnya menjadi PPK BLU/BLUD.
\end{abstract}

Kata Kunci: Badan Layanan Umum Daerah (BLUD), Kinerja Pelayanan Publik

\begin{abstract}
With all the limitations of the current government budgeting system, not all government affairs and development to realize the welfare for the people can not may be all financed by APBD. East Java provincial government is currently pushing the Regional Technical Implementation Unit (UPTD) in SKPD environment began to use financial management system Regional Public Service Agency (BLUD). The policy is clearly stated in East Java Fiscal Policy Innovation Roadmap 2014-2019. The purpose of this study is to (1). To identify the condition of UPT-UPT in East Java Provincial Government (2). Identify the problems and challenges faced in developing the UPTD into BLUD and (3). To formulate development strategy that can be done by East Java Provincial Government in developing UPTD become BLUD. The research method used is mixed method that combines qualitative data analysis with quantitative data using SWOT matrix, then to determine the strategic position and direction of development is done through analysis of General Electrics (GE) matrix. Population in this research is all Technical Implementation Unit (UPT) in East Java Provincial Government, while the sampling is done pursuant to purposive sampling. The results showed (1). UPT such as UPT P2SKP Mayangan, UPT P2SKP Pondokdadap, UPT P2SKP Muncar, and UPT PSMB-LT ready if improved status becomes BLUD see the factor of financial ability, completeness of facilities and infrastructure and its potentials (2). Some UPTs such as UPT PB Palawija, UPT PB Holtikultura, and UPTIK Timber can be upgraded to BLUD, but need to be prepared in advance, especially supporting infrastructure, especially technology aspects of technology and supporting human resources, as well as capital and promotion to develop into wider market. (3). While the Training Unit (BLKI) of Singosari and Jember, due to the specific service characteristic and the special service segment so that the dependence on the APBD/APBN is still very high, it is still difficult in terms of its existence to be upgraded to PPK BLU/BLUD.
\end{abstract}

Keywords: Local community service agency (BLUD), Performance of Public Service 


\section{PENDAHULUAN}

Salah satu agenda reformasi keuangan negara adalah adanya pergeseran dari pengganggaran dengan pola tradisional menjadi pengganggaran berbasis kinerja. Melalui basis kinerja ini, orientasi penggunaan sumber daya pemerintah tidak lagi berorientasi pada input, tetapi pada output. Hal ini penting mengingat sumber daya pemerintah yang makin terbatas, akan tetapi dituntut memenuhi tuntutan kebutuhan pembangunan yang terus meningkat dan semakin kompleks. Hal ini mendorong pemerintah terus mencari terobosan dengan cara yang lebih efektif untuk terus meningkatkan pelayanan kepada publik. Atas dasar tersebut pemerintah kemudian melakukan kebijakan reformasi keuangan negara yang mulai digulirkan mulai tahun 2003, dengan diterbitkanya tiga paket peraturan keuangan negara yang baru, yaitu Undang-undang Nomor 17 tahun 2003 tentang Keuangan Negara, Undang-undang Nomor 01 Tahun 2004 tentang Perbendaharaan Negara, dan Undang-undang Nomor 15 Tahun 2004 tentang Pemeriksaan Pengelolaan dan Tanggung Jawab Keuangan Negara. Melalui ketiga paket peraturan perundang-undangan tersebut telah dicanangkan sebuah paradigma pengelolaan keuangan negara baru yang memperhatikan tiga aspek manajemen keuangan negara, yaitu orientasi pada hasil atau mutu pelayanan, profesionalitas, serta transparansi dan akuntabilitas.

Melalui penerapan PPK BLU/D diharapkan akan merubah mindset atau pola pikir birokrasi pelayanan menjadi lebih efisien, profesionalitas, akuntabel, dan transparan, yang dilakukan melalui perubahan dari penganggaran tradisional menjadi penganggaran berbasis kinerja. Selain itu arah penggunaan Sumber Daya (Resources) akan lebih jelas penggunaanya, dari yang selama ini hanya membiayai input dan proses, harus menjadi lebih berorientasi pada output. Hal ini dimaksudkan untuk memangkas ketidakefisienan yang selama ini terjadi di dalam tubuh birokrasi. Sudah menjadi pandangan umum di masyarakat birokrasi dipersepsikan memiliki kinerja negatif (red tape), kinerja birokrasi pemerintah selama ini dinilai sebagai organisasi yang birokratis, tidak efisien, lambat dan tidak efektif. Padahal dalam manajemen modern unit pemerintahan semakin dituntut harus profesional akuntabel dan transparan. Pendekatan penganggaran berbasis output merupakan sebuah tuntutan untuk dilakukan di hampir semua satuan kerja instansi pemerintah tidak terkecuali instansi pemerintah yang memberikan pelayanan kepada publik.

Secara teoritik kebijakan terbaik untuk memangkas ketidakefisienan birokrasi dan untuk mendorong peningkatan pelayanan masyarakat adalah dengan mewiraswastakan pemerintah. Pendapat tersebut diungkapkan Richard C Box (1999) bahwa pelayanan publik tidak harus diselenggarakan oleh lembaga birokrasi murni, akan tetapi dapat diselenggarakan oleh instansi yang dikelola seperti layaknya organisasi bisnis dengan menerapkan prinsip-prinsip kewirausahaan, dan manajemen sektor swasta. Kesimpulan dari pendapat tersebut adalah apabila satuan kerja instansi pemerintah yang memberikan pelayanan kepada publik dikelola secara professional akan dapat menerapkan pola pengelolaan keuangan yang fleksibel, berupa keleluasaan untuk menerapkan praktek-praktek manajemen bisnis yang sehat seperti produktivitas, efisiensi, dan efektifitas, sekaligus dapat memaksimalkan pelayanan kepada masyarakat.

Sehingga tepat kebijakan pemerintah yang menempatkan PPK BLU/D sebagai organisasi sektor publik untuk mendorong peningkatkan kinerja pelayanan publik. Dalam Pasal 1 ayat 23 Undang-Undang Nomor 01 Tahun 2004 tentang Perbendaharaan Negara yang menyebutkan bahwa BLU adalah instansi di lingkungan Pemerintah yang dibentuk untuk memberikan pelayanan kepada masyarakat berupa penyediaan barang dan/atau jasa yang dijual tanpa mengutamakan mencari keuntungan (not-for-profit) dan dalam melakukan kegiatannya didasarkan pada prinsip efisiensi dan produktivitas. Selain itu melalui PPK BLU/D akan menjamin fleksibilitas dalam pengelolaan keuangan yaitu berupa pendapatan fungsional yang dapat langsung digunakan untuk kegiatan operasional pelayanan tanpa harus disetor ke kas daerah terlebih dahulu, selain itu dengan otonomi pengelolaan yang diberikan akan mendorong perubahan pola manajemen dan paradigma seluruh unsur di dalam organisasi BLU/D tersebut sehingga pada akhirnya tingkat pelayanan masyarakat dapat ditingkatkan dengan cara yang lebih profesional, efektif dan efisien. Sehingga kebijakan perintah yang selama ini salah dan kurang tepat memberikan subsidi tidak terjadi lagi, sehingga anggaran akan terfokus pada pelayanan "public goods". Melalui pemahaman tersebut pemerintah pusat mendorong agar pemerintah daerah agar segera membentuk Badan Layanan Umum Daerah (BLUD), hal ini diakomodasi dalam Pasal 346 Undangundang Nomor 23 Tahun 2014 tentang Pemerintah Daerah. Kemudian melalui Permendagri Nomor 52 Tahun 2015 dan Permendagri 31 Tahun 2016, Pemerintah Daerah diwajibkan untuk menginventarisasi SKPD atau Unit Kerja pada SKPD yang secara operasional memberikan pelayanan langsung kepada masyarakat agar menerapkan PPK-BLUD.

Dengan segala keterbatasan sistem penganggaran saat ini maka tidak semua urusan pemerintahan untuk mewujudkan kesejahteraan rakyat tidak dapat/mungkin 
semuanya dibiayai oleh APBD. Terlihat dari kondisi kemampuan keuangan Provinsi Jatim yang mengalami stagnasi dalam realisasi Penerimaan Anggaran Daerah (PAD) dalam tiga tahun terakhir, hal ini merupakan dampak dari dinamika global yang menyebabkan perlambatan ekonomi hampir di semua negara, termasuk Indonesia. Sehingga Provinsi Jatim harus menyusun kebijakan anggaran secara hati-hati. Dengan kondisi tersebut besaran belanja APBD Provinsi Jatim 2017 hanya mencapai Rp 23,6 Triliun, hampir sama dengan APBD murni 2016 lalu sebesar Rp 23 triliun. Anggaran tersebut diprioritaskan untuk infrastruktur, kesehatan, ekonomi serta pendidikan. Termasuk juga anggaran untuk memenuhi peralihan SMA/SMK dari pemerintah kabupaten/kota menjadi kewenangan Pemerintah provinsi. Menghadapi kondisi tersebut Pemerintah Provinsi Jawa Timur saat ini sedang mendorong Unit Pelaksana Teknis Daerah (UPTD) yang ada di lingkungan SKPD mulai menggunakan sistem pengelolaan keuangan Badan Layanan Umum (BLU/D). Kebijakan tersebut tercantum secara jelas dalam Roadmap Inovasi Kebijakan Fiskal Pemprov Jatim 20142019. Tujuannya adalah agar Organisasi Perangkat Daerah (OPD) tersebut bisa mencari anggaran sendiri dan kemudian dikelola kembali untuk memenuhi kebutuhan operasional.

Berdasarkan data Direktorat Jenderal Bina Keuangan Daerah Kementerian Dalam Negeri (2015) di lingkungan Pemprov Jatim terdapat 17 SKPD/Unit Kerja yang telah berstatus BLUD, 12 Unit sudah berstatus penuh sedang 5 masih berstatus bertahap. Sebagian besar Organisasi Perangkat daerah (OPD) tersebut yaitu 14 adalah bidang pelayanan kesehatan, dan 3 BLUD bidang pendidikan. Masih banyak di lingkungan Pemerintah Provinsi Jatim satuan kerja yang berpotensi untuk dikelola secara lebih efisien dan efektif sehingga dapat ditingkatkan statusnya menjadi BLUD. Beberapa UPT tersebut telah mampu mengelola unit kerjanya secara baik baik, bahkan beberapa bisa dikatakan mandiri, meskipun sebagian besar masih bergantung pada dana APBD. Akan tetapi tidak semua UPT tersebut secara otomatis bisa di BLUD, dalam Permendagri 61 tahun 2007 untuk melaksanakan ketentuan Pasal 150 Peraturan Pemerintah Nomor 58 Tahun 2005 tentang Pengelolaan Keuangan Daerah UPT yang bisa menjadi BLUD harus memenuhi persyaratan diantaranya Persyaratan substantif sebagaimana dimaksud dalam Pasal 4 terpenuhi apabila tugas dan fungsi SKPD atau Unit Kerja bersifat operasional dalam menyelenggarakan pelayanan umum yang menghasilkan semi barang/jasa publik (Quasi Public Goods).

Sebagai sebuah konsep baru, dan mulai dikembangkan di Indonesia perkembangan transformasi
UPT menjadi PPK BLUD menarik untuk dikaji. Mengingat pentingnya posisi UPT sebagai gugus terdepan dalam pelayanan publik di Jawa Timur, maka transformasi ini merupakan bagian daripada langkah Pemerintah Propinsi Jawa Timur untuk mengatasi keterbatasan anggaran (fiscal space) yang sedang dialami sekaligus berupaya mengoptimalkan kekuatan yang dimilikinya untuk memacu kualitas pelayanan publik. Atas dasar tersebut dapat rumusan maslaah dalam penelitian ini adalah" (1). Bagaimana kondisi UPT-UPT di lingkungan Satuan kerja Pemerintah Provinsi Jatim saat ini?. (2). Apa saja masalah dan tantangan yang dihadapi dalam pengembangan UPT-UPT tersebut menjadi BLUD?. (3). Strategi pengembangan yang dapat dilaksanakan Pemerintah Provinsi Jawa Timur dalam pengembangan UPT-UPT tersebut menjadi BLUD?

\section{METODE}

Metode yang digunakan dalam penelitian ini adalah metode penelitian campuran atau mix methods. Penelitian campuran adalah sebuah metodologi yang memberikan asumsi filosofis dalam menunjukkan arah atau memberi petunjuk cara pengumpulan data dan menganalisis data serta perpaduan pendekatan kuantitatif dan kualitatif melalui beberapa fase proses penelitian Creswell (2010), tujuanya adalah untuk saling melengkapi gambaran hasil studi mengenai fenomena yang diteliti dan untuk memperkuat analisis penelitian.

Desain penelitian menggunakan metode campuran sekuensial/bertahap (sequential mixed methods) terutama strategi ekploratoris sekuensi, yaitu mengumpulkan dan analisis data kualitatif pada tahap pertama, yang kemudian diikuti oleh pengumpulan data kuantitatif pada tahap kedua yang didasarkan hasil-hasil tahap pertama. Setelah semua informasi kualitatif yang berpengaruh terhadap pengembangan organisasi diidentifikasi, tahapan selanjutnya adalah menganalisis data dengan memanfaatkan semua informasi tersebut ke dalam bentuk kuesioner yang dibagikan kepada 50 responden yaitu terdiri dari para Pimpinan UPT, Pejabat pengelola keuangan, pejabat fungsional, Pejabat SKPD Kab/kota terkait, dan stakeholder, tahapan selanjutnya adalah menganalisis data dengan memanfaatkan semua informasi tersebut ke dalam model-model kuantitatif perumusan strategi mellaui matrik SWOT, kemudian untuk menentukan posisi strategis dan arah pengembangan dilakukan melalui analisis General Electrics (GE) matriks.

Lokus penelitian ini dilakukan di Unit Pelaksana Teknis Daerah (UPTD) di lingkungan Pemprov Jatim. Dengan waktu pelaksanaan penelitian selama 12 (Dua Belas) bulan, terhitung mulai bulan Januari sampai 
dengan Desember 2017 dengan menggunakan Anggaran Pendapatan dan Belanja Daerah (APBD) Provinsi Jawa Timur.

\section{HASIL DAN PEMBAHASAN}

Berdasarkan Matriks General Electrics (GE) sehingga akan tampak strategi dana arah pengembangan yang sesuai bagi UPT ketika akan berntransfromasi menjadi Badan Layanan Umum Daerah (BLUD).

Tabel 1 Matriks General Electrics (GE)

\begin{tabular}{|c|c|c|c|}
\hline No. & Instansi & $\begin{array}{l}\text { Nilai Matriks } \\
\text { SWOT/GE }\end{array}$ & $\begin{array}{c}\text { Posisi Strategis dan } \\
\text { Arah Pengembangan }\end{array}$ \\
\hline 1 & $\begin{array}{l}\text { UPT P2SKP Mayangan } \\
\text { Probolinggo }\end{array}$ & IFAS 3.18, EFAS 3.03 & $\begin{array}{l}\text { Konsentrasi melalui integrasi } \\
\text { vertical atau sel } 1\end{array}$ \\
\hline 2 & \begin{tabular}{|lrl} 
UPT & P2SKP & Muncar \\
Banyuwangi & \\
\end{tabular} & IFAS 2.62, EFAS 3.07 & $\begin{array}{l}\text { Konsentrasi melalui integrasi } \\
\text { horisontal atau sel } 2\end{array}$ \\
\hline 3 & $\begin{array}{|lr|}\text { UPT } & \text { P2SKP } \\
\text { Pondokdadap Malang }\end{array}$ & IFAS 3.17, EFAS $=3.09$ & $\begin{array}{l}\text { Konsentrasi melalui integrasi } \\
\text { vertikal atau sel } 1\end{array}$ \\
\hline 4 & 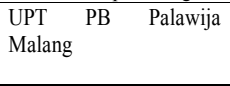 & IFAS 2.58, EFAS $=2.31$ & $\begin{array}{l}\text { Konsentrasi melalui integrasi } \\
\text { horisontal atau stability profit } \\
\text { strategi atau berada pada sel } 5\end{array}$ \\
\hline 5 & 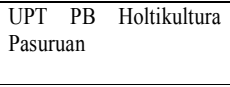 & IFAS 3.01, EFA & $\begin{array}{l}\text { Strategi pertumbuhan melalui } \\
\text { konsentrasi dan diversifikasi } \\
\text { atau berada pada sel } 7\end{array}$ \\
\hline 6 & \begin{tabular}{ll|} 
UPT & BLKI Singosari \\
Malang &
\end{tabular} & IFAS $3.00, \mathrm{I}$ & $\begin{array}{l}\text { Strategi pertumbuhan melalui } \\
\text { konsentrasi dan diversifikasi } \\
\text { atau berada pada sel } 7\end{array}$ \\
\hline 7 & UPT BLKI Jember & IFAS 2.46, EFAS 1.92 & $\begin{array}{l}\text { Strategi diversifikasi } \\
\text { konglomerasi atau berada pada } \\
\text { sel } 8\end{array}$ \\
\hline 8 & UPT PSMB-LT Jember & IFAS 3.08, EFAS 3.22 & $\begin{array}{l}\text { Strategi konsentrasi melalui } \\
\text { Integrasi vertikal atau berada } \\
\text { pada sel 1 }\end{array}$ \\
\hline 9 & UPTIK Kayu Pasuruan & IFAS 2.76, EFAS 2.98 & $\begin{array}{l}\text { Konsentrasi melalui integrasi } \\
\text { horisontal atau stability profit } \\
\text { strategi atau berada pada sel } 5\end{array}$ \\
\hline
\end{tabular}

Berdasarkan hasil analisis dan perhitungan serta temuan di lapangan, secara umum dapat diidentifikasi kondisi eksisting, faktor pendukung dan penghambat serta strategi dan arah pengembangan pengembangan yang harus dilakukan ketika organisasi Unit Pelaksana Teknis Dinas (UPTD) akan didorong untuk bertransformasi menjadi Badan Layanan Umum Daerah (BLUD):

\section{Posisi Strategis dan arah Pengembangan UPT P2SKP Mayangan Probolinggo apabila bertransformasi menjadi Badan Layanan Umum Daerah (BLUD)}

Hasil Analisis SWOT dan Analisis General Electrics (GE) menunjukkan bahwa posisi strategis dan arah pengembangan UPT P2SKP Mayangan Probolinggo berada pada daya tarik kuat dan kekuatan persaingan tinggi, sehingga strategi pengembangan yang sesuai bagi UPT P2SKP Mayangan Probolinggo adalah konsentrasi melalui integrasi vertikal atau sel 1 yaitu menjaga pertumbuhan, dominasi, dan memaksimalkan investasi. Keuntungan yang diperoleh dari integrasi vertikal ini adalah menurunkan biaya operasional, memaksimalkan keuntungan serta menjamin stabilitas pertumbuhan melalui koordinasi dan kontrol (Wheelen, 2001:45).

Kondisi ini menunjukan bahwa strategi pertumbuhan yang paling tepat untuk UPT P2SKP Mayangan Probolinggo adalah menjaga stabilitas pertumbuhan melalui peningkatkan kualitas pelayanan serta meningkatkan sarana dan prasarana yang ada di pelabuhan. Dengan posisi pertumbuhan yang kuat tersebut organisasi disarankan untuk memperkuat dominasi dengan cara mengambil alih sebagian atau sebagian besar fungsi supplier (backward integration) dan fungsi distributor (forward integration), strategi tersebut diharapkan akan memaksimalkan pendapatan sekaligus menjamin stabilitas pasokan dan harga di tingkat nelayan dan pelaku usaha kecil di wilayah pelabuhan. Pada saat yang sama, karena berada pada pertumbuhan pasar yang kuat dan persaingan yang tinggi maka hal ini menjadi saat yang tepat bagi organisasi untuk menyesuaikan besaran nilai sewa lahan dan biaya jasa/retribusi pelayanan dengan besaran yang lebih ekonomis serta wajar, selain itu juga dimungkinkan untuk memperluas jenis pelayanan yang ada saat ini.

Melihat posisi strategis dan arah pengembangan UPT P2SKP Mayangan Probolinggo apabila bertransformasi Badan Layanan Umum Daerah (BLUD) dapat ditentukan beberapa langkah strategis yang perlu dilakukan yaitu : (1) Meningkatkan kualitas sarana dan prasarana, baik itu fasilitas pokok, fasilitas fungsional dan fasilitas penunjang operasional pelabuhan, Memperluas area untuk galangan kapal (docking /bengkel kapal) agar bisa menampung kapal lebih banyak, (3) Mengembangkan pabrik es batu di lokasi pelabuhan, selama ini masih disuplai dari luar wilayah pelabuhan, (4) Kemungkinan untuk mengelola sendiri SPDN (BBM) yang saat ini masih dikelola oleh pihak ketiga, (5) Kordinasi dengan Kab/kota terkait besaran retribusi TPI yang diterima UPT P2SKP Mayangan Probolinggo masih belum layak (regulasi), (6) Membangun koperasi simpan pinjam bagi para nelayan dan pelaku usaha yang beroperasi di pelabuhan Mayangan agar mereka tidak terjerat oleh para tengkulak

\section{Posisi Strategis dan arah Pengembangan UPT P2SKP Muncar Banyuwangi apabila bertransformasi menjadi Badan Layanan Umum Daerah (BLUD)}

Hasil Analisis SWOT dan Analisis General Electrics (GE) menunjukkan bahwa posisi strategis dan arah pengembangan UPT P2SKP Muncar Banyuwangi berada pada daya tarik usaha menengah dan memiliki kekuatan persaingan kuat, sehingga strategi pengembangan yang sesuai bagi UPT P2SKP Muncar adalah konsentrasi melalui integrasi horisontal atau sel 2, 
atau organisasi berada dalam industri yang sangat atraktif. Strategi pengembanganya adalah mengidentifikasi segmen pertumbuhan, melakukan investasi besar-besaran, serta mempertahankan posisi dimana saja (Wheelen, 2001:45).

Kondisi ini menunjukkan posisi pertumbuhan dimana organisasi harus meningkatkan daya tarik usaha jika ingin memaksimalkan pendapatan. Organisasi harus segera mengidentifikasi segmen bisnis atau pelayanan mana yang bisa dikembangkan, segera memperbaiki kelemahan-kelemahan yang ada yang menghambat penerimaaan pendapatan, serta melakukan investasi untuk mengembangkan sarana dan prasarana pendukung pelabuhan. Dengan begitu potensi penerimaan baik dari biaya jasa di pelabuhan maupun usaha pendukung lainnya dapat lebih dimaksimalkan lagi. Sedangkan dari aspek SDM kekurangan pegawai juga harus diperhatikan, akan tetapi yang perlu diingat bahwa dalam pengelolaan BLU/BLUD pimpinan bisa saja berasal dari non PNS (professional) akan tetapi pengelola keuangan haruslah berasal dari PNS sebab yang bersangkutan akan bertindak sebagai kuasa pengguna anggaran/barang daerah. BLU/BLUD memang diperkenankan merekrut tenaga professional dari luar apakah itu outsourcing atau tetap, bergantung kebutuhan masing-masing lembaga

Melihat posisi strategis dan arah pengembangan UPT P2SKP Muncar Banyuwangi apabila bertransformasi Badan Layanan Umum Daerah (BLUD) dapat ditentukan beberapa langkah strategis yang perlu dilakukan yaitu : (1) Menambah dan merevitalisasi sarana dan prasarana, baik itu fasilitas pokok, fasilitas fungsional dan fasilitas penunjang operasional, (2) Retribusi dari biaya tambat labuh masih kecil sehingga perlu diperluas lagi bagi kapal-kapal <20 GT yang jumlahnya cukup besar (3) Meningkatkan pendapatan dari retribusi TPI yang saat ini masih sangat kecil, (4) Pengerukan sedimentasi dengan perencanaan agar kapal-kapal besar dapat masuk, (5) Mengoptimalkan pendapatan Retribusi pas masuk dengan membuat pagar di sekeliling pelabuhan untuk membatasi dengan area permukiman, (6) Pengembangan investasi pelabuhan seperti Pasar ikan Transit, Industri (packing ikan), dan lahan seluas $8 \mathrm{Ha}$.

\footnotetext{
Posisi Strategis dan arah Pengembangan UPT P2SKP Pondokdadap Malang apabila bertransformasi menjadi Badan Layanan Umum Daerah (BLUD)
}

Hasil Analisis SWOT dan Analisis General Electrics (GE) menunjukkan bahwa posisi strategis dan arah pengembangan UPT P2SKP Pondokdadap Malang berada pada daya tarik kuat dan kekuatan persaingan tinggi, Sehingga strategi pengembangan yang sesuai adalah konsentrasi melalui integrasi vertikal atau sel 1 . Strategi ini sesuai dengan posisi UPT P2SKP Pondokdadap Malang yang berada dalam industri yang sangat atraktif, yaitu daya tarik industri sangat tinggi dan kekuatan internal bisnis adalah strategi pertumbuhan dengan konsentrasi melalui integrasi vertical dengan cara backward integration (mengambil alih fungsi supplier) atau dengan cara forward integration (mengambil alih fungsi distributor). Keuntungan yang diperoleh dari integrasi vertikal ini adalah turunnya biaya operasional serta menjamin koordinasi dan kontrol (Wheelen, 2001:45).

Kondisi ini menunjukkan strategi pertumbuhan UPT P2SKP Pondokdadap Malang adalah mempertahankan pertumbuhan melalui peningkatan baik jumlah maupun kualitas sarana dan prasarana di pelabuhan serta penunjang kegiatan pelabuhan. Posisi organisasi yang berada pada pertumbuhan kuat seringkali juga mencari dominasi dengan cara mengambil alih fungsi supplier atau mengambil alih fungsi distributor. Pada saat yang sama, karena berada pada pertumbuhan pasar yang kuat dan persaingan yang tinggi maka saat ini perlu untuk segera melakukan langkah-langkah strategis untuk memperluas area pelayanan yang mendukung penerimaan pendapatan.

Dengan posisinya yang strategis serta didukung dengan sarana dan prasarana yang memadai serta potensi yang dimiliki membuat ketiga pelabuhan ini sangat layak untuk ditingkatkan statusnya menjadi PPK BLU/BLUD. Beberapa langkah yang mendesak untuk dilakukan adalah menyelesaikan permasalahan yang membuat potensi penerimaan kurang maksimal, diantaranya adalah (1). Menata kembali besaran tarif baik itu tarif layanan maupun nilai sewa lahan dengan memperhatikan aspek kontinuitas dan pengembangan layanan, daya beli masyarakat, keadilan dan kepatutan, serta kompetisi yang sehat, Saat ini yang berlaku adalah Peraturan Daerah Pemerintah Provinsi Jawa Timur Nomor 1 Tahun 2012 dan Nomor 15 Tahun 2013 tentang Retribusi Daerah serta Peraturan Gubernur Jawa Timur Nomor 29 Tahun 2016. Dibutuhkan mekanisme regulasi lebih flexible, kedepan dapat dipertimbangkan untuk mendelegasikan kewenangan penetapan tarif/retribusi layanan tersebut didelegasikan kepada pimpinan lembaga dan/atau pemimpin satker dengan memperhatikan karakteristik layanan serta pengaruhnya terhadap masyarakat umum. Hal tersebut untuk memberikan keleluasaan bagi 
instansi dalam menghadapi tantangan dan perubahan dalam pemberian jasa layanannya.

Melihat posisi strategis dan arah pengembangan UPT P2SKP Pondokdadap Malang apabila bertransformasi Badan Layanan Umum Daerah (BLUD) beberapa langkah strategis yang perlu dilakukan adalah: (1) Mengembangkan sarana dan prasarana pelabuhan, baik itu fasilitas pokok, fasilitas fungsional dan fasilitas penunjang operasional pelabuhan seperti docking (bengkel kapal), pabrik es batu, cold strorage dll, pembiayaan bisa dilakukan sendiri maupun joint venture dengan pihak lain (2). Melakukan pengerukan dermaga, karena pada saat surut menganggu tambat labuh kapal, (3). Koordinasi dengan pihak terkait untuk mempercepat proses sertifikasi tanah, karena sebagian besar lahan adalah dalam kawasan hutan lindung sehingga kesulitan dalam proses pendaftaran tanah (4). Pembuatan pagar pembatas yang permanen di sekeliling area pelabuhan untuk memaksimalkan potensi pendapatan yang hilang seperti retribusi pas masuk, sewa lahan dll (5) Pengembangan area pelabuhan sebagai lokasi destinasi wisata

Posisi Strategis dan arah Pengembangan UPT Pengembangan Benih Palawija Malang apabila bertransformasi menjadi Badan Layanan Umum Daerah (BLUD)

Hasil Analisis SWOT dan Analisis General Electrics (GE) menunjukan bahwa posisi strategis dan arah pengembangan UPT PB Palawija memiliki kekuatan internal bisnis menengah sedangkan daya tarik industri bernilai rata-rata atau berada dalam posisi "moderate attractive industry", sehingga strategi pengembangan yang sesuai bagi UPT PB Palawija adalah konsentrasi melalui integrasi horisontal atau stability profit strategi atau berada pada sel 5 (Wheelen, 2001:45). Tujuan dari strategi ini adalah relative defensive atau tidak melakukan perubahan profit strategi apapun, yaitu untuk menghindari potensi kehilangan pendapatan yang berakibat terganggunya operasional organisasi. Strategi ini menekankan pada tidak bertambahnya produk, pasar, dan fungsi-fungsi lain karena organisasi berusaha untuk meningkatkan efisiensi di segala bidang dalam rangka meningkatkan kinerja dan keuntungan. Strategi ini resikonya relatif rendah dan biasanya dilakukan untuk produk yang tengah berada pada posisi kedewasaan (mature).

Melihat posisi strategis dan arah pengembangan UPT Pengembangan Benih Holtikultura apabila bertransformasi Badan Layanan Umum Daerah (BLUD) beberapa langkah strategis yang perlu dilakukan adalah : (1). Mempertahankan dan meningkatkan mutu benih, (2). Fokus pada peningkatan produksi benih yang permintaan tinggi seperti kedelai, kacang tanah, dan kacang hijau selalu lebih tinggi daripada persediaan, (3). Pola penganggaran perbenihan yang fleksibel dimana musim tanam sangat tergantung terhadap cuaca, (4). Melakukan diversifikasi produk benih yang sesuai kebutuhan masyarakat, (6). Membangun jaringan distribusi dan meningkatkat promosi pasar, (7). Meningkatkan kerjasama dengan instansi lain untuk memperluas akses ke pasar yang lebih luas, (8). Investasi pada sarana dan prasarana produksi benih yang lebih modern, (9). Revitalisasi sistem pengairan (irigasi), (10). Memanfaatkan sistem informasi cuaca untuk manjadwalkan penangkaran yang tepat musim.

Posisi Strategis dan arah Pengembangan UPT Pengembangan Benih (UPT PB) Holtikultura Pasuruan apabila bertransformasi menjadi Badan Layanan Umum Daerah (BLUD)

Hasil Analisis SWOT dan Analisis General Electrics (GE) menunjukan bahwa posisi strategis dan arah pengembangan UPT PB Holtikultura yang memiliki kekuatan daya tarik usaha yang kuat akan tetapi kondisi kompetitifnya lemah, sehingga strategi pengembangan yang sesuai bagi UPT PB Holtikultura adalah strategi pertumbuhan melalui konsentrasi dan diversifikasi atau berada pada sel 7 (Wheelen, 2001:45). Langkah strategis yang dapat dilakukan adalah tumbuh melalui integrasi horizontal maupun vertikal, baik secara internal menggunakan kekuatan sumber daya yang dimiliki saat ini atau secara eksternal dengan menggunakan sumber daya dari luar melalui kerjasama, strategi intensif maupun strategi diversifikasi.

Menurut David (2002:17) Strategi Integrasi Vertikal adalah strategi yang menghendaki agar perusahaan melakukan pengawasan yang lebih terhadap distributor, pemasok, dan atau para pesaingnya, misalnya melalui merger, akuisisi, atau membuat perusahaan sendiri. Strategi Intensif adalah usaha-usaha yang intensif untuk meningkatkan posisi persaingan perusahaan melalui produk yang ada. Sedangkan Strategi Diversifikasi dimaksudkan untuk untuk menambah produk-produk baru, strategi ini kurang populer, paling tidak ditinjau dari sisi tingginya tingkat kesulitan manajemen dalam mengendalikan aktivitas perusahaan yang berbeda-beda.

Melihat posisi strategis dan arah pengembangan UPT Pengembangan Benih Holtikultura apabila bertransformasi Badan Layanan Umum Daerah (BLUD) beberapa langkah strategis yang perlu dilakukan adalah : (1). Fokus pada pengembangan varietas produk yang paling diminati pasar, (2). Revitalisasi sarana dan 
prasarana penunjang produksi, baik peralatan, laboratorium, maupun saluran irigasi, (3). Pengembangan produk olahan melalui kerjasama baik dengan lembaga riset maupun perusahaan, (4). Penjadwalan produksi yang tepat waktu dan jumlah serta secara berkala melakukan analisa kebutuhan pasar, (5). Pembenahan sistem manajemen SDM dan merekrut tenaga baru, (6). Meningkatkan akses permodalan untuk meningkatkan produksi, (7). Melakukan kemitraan baik dengan swasta maupun instansi lain untuk pengembangan pasar, meningkatkat promosi pasar, (8). Meningkatkan kerjasama dengan instansi lain untuk memperluas akses ke pasar yang lebih luas, (9). Investasi pada sarana dan prasarana produksi benih yang lebih modern, dan yang terakhir beberapa kelamahan terutama mengenai kakteristik produk dan daya simpan dan kualitas hortikultura yang rentan rusak, ditambah lagi pemasaran, promosi, dan distribusi masih belum maksimal. (10). Sehingga diperlukan strategi penjadwalan produksi yang tepat guna dan analisa pasar sangat diperlukan.

Posisi Strategis dan arah Pengembangan UPT Pelatihan Kerja (BLKI) Singosari Malang apabila bertransformasi menjadi Badan Layanan Umum Daerah (BLUD)

Hasil Analisis SWOT dan Analisis General Electrics (GE) menunjukan posisi strategis dan arah pengembangan UPT BLKI Singosari Malang memiliki kekuatan internal bisnis atau competitive positioning sangat kuat tetapi nilai daya tarik industri rendah, sehingga strategi pengembangan yang sesuai bagi UPT BLKI Singosari Malang adalah strategi pertumbuhan melalui konsentrasi dan diversifikasi atau berada pada sel 7 (Wheelen, 2001:45). Langkah strategis yang dapat dilakukan dilakukan adalah spesialisasi, mencari segmen yang menguntungkan, dan mempertimbangkan akuisisi maupun kerjasama.

Melihat posisi strategis dan arah pengembangan UPT Pelatihan Kerja (BLKI) Singosari Malang apabila bertransformasi Badan Layanan Umum Daerah (BLUD) beberapa langkah strategis yang perlu dilakukan adalah : (1) Memperluas jenis produk pelatihan baik model pelatihan baru maupun modifikasi dari pelatihan yang sudah ada secara lebih efisien baik secara metodologi dan kurikulum terbaru yang mengakomodasi akan kebutuhan pasar tenaga kerja, (2) Melakukan spesialisasi pelatihan yang cocok dan sesuai dengan kondisi lingkungan wilayah dan kebutuhan pasar tenaga kerja di daerah (3) Pertimbangkan menghapus pelayanan yang kurang peminat dan kurang potensial, (4). Mengembangkan kerjasama dengan pihak lain (5) Sinergitas dengan pihak lain terutama TUK jejaring dan stakeholder pengguna lulusan, (6). Memanfaatkan pendanaan eksternal misalnya CSR, Dana alokasi Desa (ADD) dan Dana Bagi Hasil Cukai \& Tembakau untuk program pelatihan, (7). Optimalkan Mobile Training Unit (MTU) untuk menjangkau daerah pelayanan yang lebih luas. (8). Revitalisasi sarana dan prasarana pelatihan.

\section{Posisi Strategis dan arah Pengembangan UPT Pelatihan Kerja (BLKI) Jember apabila bertransformasi menjadi Badan Layanan Umum Daerah (BLUD)}

Hasil Analisis SWOT dan Analisis General Electrics (GE) menunjukkan bahwa posisi strategis dan arah pengembangan UPT BLKI Jember memiliki kekuatan kompetitif lemah dan nilai daya tarik usaha menengah, sehingga strategi pengembangan yang sesuai bagi UPT BLKI Jember adalah strategi diversifikasi konglomerasi atau berada pada sel 8 (Wheelen, 2001:45). Beberapa langkah yang dapat ditempuh adalah melakukan spesialisasi, mencari potensi yang bisa dikebangkan, dan mempertimbangkan menghapus beberapa pelayanan.

Melihat posisi strategis dan arah pengembangan UPT Pelatihan Kerja (BLKI) Jember apabila bertransformasi Badan Layanan Umum Daerah (BLUD) beberapa langkah strategis yang perlu dilakukan adalah: (1) Mengembangkan jenis pelatihan yang sesuai kebutuhan pasar tenaga kerja. (2) Melakukan spesialisasi pelatihan yang cocok dan sesuai dengan kondisi lingkungan wilayah dan kebutuhan pasar tenaga kerja di wilayah sekitar kabupaten jember yang karakteristiknya pertanian dan perkebunan, (3) Identifikasi potensi kerjasama CSR dengan pihak lain, (4) Optimalkan kerjasama dan kordinasi dengan TUK jejaring untuk meningkatkan kualitas dan melengkapi kelemahan, (4) Pertimbangkan untuk menghapus program pelatihan yang kurang peminat, (5). Koordinasi dengan Dinas Kab/kota mengenai potensi penggunaan Dana Desa (ADD) dan Dana Bagi Hasil Cukai dan Tembakau (DBHCT) untuk progam pelatihan, (6). Revitalisasi sarana dan prasarana pelatihan, Sehingga apabila tetap didorong untuk menjadi BLUD maka yang dapat dilakukan adalah pada pengembangan pelatihan swadana (biaya sendiri) ataupun pelatihan kerjasama. Dengan demikian yang bisa dikembangkan adalah memanfaatkan pendanaan eksternal misalnya CSR, Dana alokasi Desa (ADD) dan Dana Bagi Hasil Cukai \& Tembakau untuk program pelatihan, kemampuan menjalin komunikasi dan kordinasi dengan pihak stakeholder sangat diperlukan. Strategi lainya adalah mengoptimalkan fungsi Mobile Training Unit (MTU) untuk menjangkau daerah pelayanan yang lebih luas. Dengan demikian di satu 
sisi BLKI masih memberikan pelatihan gratis kepada para peserta pelatihan dengan menggunakan skema APBN/APBD, disisi lain BLKI juga mempu menjaga kemandirian melalui pendanaan pelatihan dengan pihak ketiga.

Posisi Strategis dan arah Pengembangan UPT Pengujian Sertifikasi Mutu Barang Lembaga Tembakau (UPT PSMB-LT) Jember apabila bertransformasi menjadi Badan Layanan Umum Daerah (BLUD)

Hasil Analisis SWOT dan Analisis General Electrics (GE) menunjukkan bahwa posisi strategis dan arah pengembangan UPT PSMB-LT Jember dimana memiliki kekuatan internal bisnis kuat atau kompetitif kuat dan nilai daya tarik usaha juga kuat, sehingga strategi pengembangan yang sesuai bagi UPT PSMBLT Jember adalah strategi Konsentrasi melalui Integrasi vertikal atau berada pada sel 1 (Wheelen, 2001:45). Pada posisi ini langkah yang dapat dilakukan oleh organisasi untuk memngembangkan diri adalah mencari dominasi melalui peningkatkan sumbersumber pendapatan baru dengan menambah ruang lingkup pelayanan, menjaga pertumbuhan melalui memaksimalkan fungsi pelayanan yang ada, meningkatkan efisiensi biaya dan operasional, investasi pada pertumbuhan, mengontrol kualitas dan distribusi produk pelayanan, dan meningkatkan akses ke pasar yang lebih luas.

Melihat posisi strategis dan arah pengembangan UPT PSMB-LT Jember apabila bertransformasi Badan Layanan Umum Daerah (BLUD) beberapa langkah strategis yang perlu dilakukan adalah : (1). Memperluas ruang lingkup pelayanan, (2). Pengadaan alat uji kalibrasi yang memiliki spesifikasi lebih kompleks, (3). Mengatur kembali tarif jasa pelayanan dengan harga yang lebih ekonomis, (4). Pengembangan produk tembakau non rokok (pengencang kulit, obat dalam bentuk nikotin tartrat, protein anti kanker, minyak astiri, parfum, barul, dan scrab herbal) melalui kerjasama baik dengan lembaga riset maupun industri (5). Menambah maupun meregenerasi alat-alat pengujian dan laboratorium yang sudah tidak efisien, (6). Memperkuat kompetensi SDM pengujian, (7). Pengembangan perpustakaan dan museum tembakau, (8). Menambah maupun meregenerasi alat-alat pengujian dan laboratorium yang sudah tidak efisien, (6). Memperkuat kompetensi SDM pengujian.
Posisi Strategis dan arah Pengembangan UPTIK Kayu Pasuruan apabila bertransformasi menjadi Badan Layanan Umum Daerah (BLUD)

Hasil Analisis SWOT dan Analisis General Electrics (GE) menunjukkan bahwa posisi strategis menunjukan bahwa posisi UPT Kayu Pasuruan memiliki kekuatan internal bisnis menengah sedangkan daya tarik industri bernilai rata-rata atau berada dalam kondisi "moderate attractive industry", sehingga strategi pengembangan yang sesuai bagi UPT Kayu Pasuruan adalah konsentrasi melalui integrasi horisontal atau stability profit strategi atau berada pada sel 5 (Wheelen, 2001:45). Dalam posisi seperti ini maka arah pengembangan dan langkah strategis yang dapat dilakukan adalah memperluas pasar, menambah fasilitas produksi, dan teknologi melalui pengembangan internal maupun eksternal melalui akuisisi atau joint venture, dan melakukan konsolidasi melalui relative defensive atau tidak melakukan perubahan profit strategi untuk menghindari potensi kehilangan pendapatan yang berakibat terganggunya operasional organisasi.

Melihat posisi strategis dan arah pengembangan UPTIK Kayu Pasuruan apabila bertransformasi Badan Layanan Umum Daerah (BLUD) beberapa langkah strategis yang perlu dilakukan adalah: (1). Memperluas akses pasar prosuk kayu pasuruan melalui pameran dan workshop produk kayu baik di dalam negeri maupun luar negeri (2). Meningkatkan akses permodalan kepada perbankan (3). Revitalisasi mesin produksi perkayuan dengan yang lebih modern, (4). Efisiensi melalui penggunaan mesin-mesin modern, (5). Menghitung ulang tarif sesuai nilai ekonomis operasional, (6). Revitalisasi mesin dengan yang lebih modern, (7). Meningkatkan akses permodalan bagi pelaku usaha kayu di pasuruan baik dengan perbankan maupun lembaga pembiayan lainnya, (8). Memperluas pasar produk kayu pasuruan melalui pameran, workshop, dan media internet, (9). Menghitung ulang tarif jasa pelayanan sesuai dengan biaya operasional, (10). Meningkatkan desain produk agar lebih beragam dan menarik bagi pasar, (11). Pengembangan produk kayu untuk produk manufaktur non mebel

\section{PENUTUP}

\section{Simpulan}

Berdasarkan hasil penelitian secara umum dapat disimpulkan bahwa kondisi dan kemampuan masingmasing UPT bervariasi, baik dari segi kemandirian, sarana prasarana, sumber daya manusia maupun karakteristik layanan apabila dilakukan kebijakan transformasi menjadi Badan Layanan Umum Daerah (BLUD) : 
1) UPT seperti UPT P2SKP Mayangan, UPT P2SKP Pondokdadap, UPT P2SKP Muncar, dan UPT PSMB-LT bisa dikatakan siap jika akan ditingkatkan statusnya menjadi PPK BLU/BLUD jika melihat faktor kemampuan keuangan, kelengkapan sarana dan prasarana serta potensi yang dimilikinya, tetapi tentu faktor pendukung harus dipersiapkan terlebih dahulu, terutama aspek regulasi yang belum sepenuhnya menjamin flexibilitas dalam pengelolaannya, masih banyak aturan baik Perda Provinsi, Pergub, Perda kab/kota dan regulasi lainnya yang menghambat UPT2 tersebut mengembangkan potensinya, terutama mengenai besaran tarif pelayanan serta masih belum sinkron mana yang menjadi wewenang provinsi dan mana wewenang pemerintahan kab/kota.

2) Beberapa UPT seperti UPT PB Palawija, UPT PB Holtikultura, dan UPT Kayu bisa saja ditingkatkan menjadi PPK BLU/BLUD, tetapi perlu ditingkatkan terlebih dahulu terutama sarana prasarana pendukung terutama teknologi aspek teknologi beserta SDM pendukungnya, dan juga permodalan serta promosi untuk mengembangkan ke pasar yang lebih luas.

3) Sedangkan UPT Pelatihan Kerja (BLKI) Singosari dan Jember, disebabkan karakter pelayananya yang spesifik yaitu visi dan misinya yang memang ditujukan untuk mengurangi pengangguran yang masih tinggi di jawa timur dan segmen pelayanan yang khusus, ketergantungan kepada APBD/APBN masih sangat tinggi sehingga akan sangat sulit dari segi kemadirian untuk ditingkatkan statusnya menjadi PPK BLU/BLUD, tetapi bukan berarti tidak mungkin. Justru dengan kemadirian dan flexibilitas potensi kemandirian dari pelayanan LSP2 dan Program pelatihan eksternal bisa ditingkatkan. Saat ini banyak sekali pendanaan yang bisa dimanfaatkan seperti misalnya CSR, Dana Alokasi Desa, dan Dana Bagi Hasil Cukai dan Tembakau. Pendekatan gabungan yaitu menggabungkan pola kemandirian PPK BLU/BLUD plus APBN/APBD bisa digunakan.

\section{Saran}

1) Kepada Pemerintah Provinsi Jawa Timur ketika akan menerapkan kebijakan PPK-BLUD harus selektif dan obyektif, karena tidak semua SKPD atau Unit Kerja yang memberi pelayanan pada masyarakat dapat menerapkan PPK-BLUD, harus dilihat kesiapan SDM-nya, sarana dan prasarana serta perangkat pendukung lainnya; selain itu BLUD merupakan quasi public goods, sehingga peran APBD/APBN masih tetap diperlukan dalam peningkatan pelayanan; terutama kepada pelayanan yang memiliki dampak kepada masyarakat luas seperti pengentasan kemisinan, mengurangi angka pengangguran dll

2) Kepada Satuan Kerja yang akan menerapkan PPKBLUD, jangan hanya mengejar fleksibilitas yang diberikan, tetapi dalam rangka peningkatan kinerja pelayanan, kinerja manfaat, dan kinerja keuangan secara keseluruhan, jangan sampai dengan berubahnya status UPT menjadi BLUD ini akan merugikan masyarakat. Yang diharapkan adalah bukan bentuknya saja UPT menjadi BLUD, akan tetapi melalui transformasi ini tingkat pelayanan masyarakat dapat ditingkatkan dengan cara yang profesional, efektif dan efisien oleh pengelola unit tersebut dengan otonomi pengelolaan yang akan diberikan

3) Perlu dilakukan koordinasi dan sinkronisasi beberapa regulasi terutama dengan pemerintah kab/kota terkait wewenang dan tanggung-jawab yang dimiliki masing-masing. Antara pemerintah provinsi dan kab/kota baik eksekutif dan legislative perlu duduk bersama untuk menyamakan perpsepsi mengenai dampak perubahan UPT menjadi BLUD, sehingga manfaatnya bisa dirasakan bersama-sama.

4) Untuk keberhasilan implementasi BLUD, perlunya peningkatan kapasitas dan kapabilitas SDM, merubah pola pikir (maindset) seluruh aspek organisasi dari yang selama ini birokratis menjadi semangat kewirausahaan (enterpreneurship), menyiapkan peraturan pendukung mengenai flexibilitas yang akan diberikan, serta dibutuhkan pemahaman yang sama tentang konsepsi BLUD mulai dari kepala daerah, sekretaris daerah, BPKAD, Kepala BAPPEDA, Inspektorat Daerah dan pejabat pengelola BLUD..

\section{DAFTAR PUSTAKA}

Darise, Nurlan, 2008, Akuntansi Keuangan Daerah (Akuntansi Sektor Publik), PT Indeks, Jakarta

David, Fred R., 2002. Manajemen Strategis Konsep, terjemahan, PT Prenhallindo, Jakarta.

Glueck, William F dan Jauch, Lawrence, 1989. Manajemen Strategi dan Kebijakan Perusahaan (2nd ed). Erlangga, Jakarta 
Hunger, J. D. and Wheelen, T. L., 2001. Strategic Management. 1996. Fifth Editions. Addison-Wesley Publishing Company, Inc. Agung J. (penterjemah).2001. Manajemen Strategis. Andi.Yogyakarta.

1994. Competitive Advantage (Keunggulan Bersaing). Edisi Bahasa Indonesia. Binarupa Aksara, Jakarta

Lukman, Mediya. (2013). Badan Layanan Umum; Dari Birokrasi Menuju Korporasi. Jakarta: Bumi Aksara.

Mahmudi. (2015). Manajemen Kinerja Sektor Publik, Yogyakarta: UPP Sekolah Tinggi Ilmu Manajemen YKPN.

Freddy Rangkuti. (2014), Analisis SWOT : Teknik Membedah Kasus Bisnis, Cetakan 18, Jakarta: PT. Gramedia Pustaka Utama.

(2016), SWOT Balanced Scorecard, Cetakan 10, Jakarta: PT. Gramedia Pustaka Utama.

Sugiyono, (2005). Memahami Penelitian Kualitatif, Alfabeta, Bandung,

(2011). Metode Penelitian Kuantitatif, Kualitatif dan R\&D. Bandung: CV. Alfabeta.

Wibowo, I. dan Wahono, (eds.), 2003, Neoliberalisme, Yogyakarta : Cinderalas.

Supriyanto, Joko dan Suparjo. Badan Layanan Umum: Sebuah Pola Pemikiran Baru atas Unit Pelayanan Masyarakat, http://www.perbendaharaan.go.id., diakses tanggal 4 Februari 2017. 